\title{
МОВНІ ЧИННИКИ Й МЕХАНІЗМИ ФОРМУВАННЯ ЯКІСНОЇ ФОРМАЛЬНО-ЗМІСТОВОЇ АСИМЕТРІЇ В ЄДНАЛЬНИХ СКЛАДНОСУРЯДНИХ РЕЧЕННЯХ
}

У статті на підставі з'ясування сутності асиметрії форми й змісту на рівні складного речення виявлено коло якісно асиметричних складносурядних єднальних конструкиій в українській мові, схарактеризовано інтрата екстралінгвальні фактори, що зумовлюють виникнення невідповідності синтаксичної форми їі ядерному змісту. Виявлено, що в досліджуваному типі речень частотними є випадки актуалізації зіставних, протиставних, приєднувальних, умовно-наслідкових, причиново-наслідкових, допустових значень.

Ключові слова: складносурядне єднальне речення, якісна асиметрія, семантика, тексичне наповнення, прагматичний чинник.

\section{Polozova O. Linguistic Factors and Mechanisms of Formation of Qualitative} Formal-Semantic Asymmetry in Compound Sentences with Copulative Coordination. The relevance of the study is due to the need to generalize information about qualitatively asymmetric manifestations at the level of compound conjunctions in the Ukrainian language on the basis of modern ideas about the mismatch of a form and a content in the structure of compound syntactic constructions.

The aim of the work is to identify the range of asymmetric compound copulative connectors with the elucidation of intra- and extralingual factors of formation of qualitative formal-semantic asymmetry in them. The subject of the research is compound conjunctions in the modern Ukrainian language. The main objectives of the study are to generalize the previous conclusions of syntaxists regarding atypical meanings in the structure of compound sentences with copulative coordination; to outline the main qualitatively asymmetric varieties of compound sentences with attention to the linguistic mechanisms of formation of atypical content in them and to explain the pragmatic nature of their appearance.

As a result of the scientific research it was found that the main manifestations of qualitative formal-semantic asymmetry at the level of compound sentences with copulative coordination are constructions with actual comparative, adversative, copulative, conditional, causative, admissible meanings. The formation of atypical meanings in the structure of compound sentences with copulative coordination most often occurs due to the specific lexical and semantic content of predicative parts. The reason for the appearance of qualitatively asymmetric copulative structures can be explained by the cognitive nature of the conjunction operation as a simple juxtaposition 
of two situations of reality in the speaker's mind, between which subjectively interpreted wide range of dependence can be gradually delineated.

Key words: compound conjunction, qualitative asymmetry, semantics, lexical content, pragmatic factor.

\section{Вступ}

Природа складносурядних речень полягає в тому, що важливе значення мають автономний статус предикативних частин цих структур і наявність формально вираженого синтаксичного зв'язку між ними. Сурядні сполучники вказують на відносну незалежність поєднуваних речень; позиція самого сполучника в сурядному зв’язку теж характеризується більшою автономністю порівняно з позицією підрядного сполучника.

Однак, як зазначають дослідники, семантика складносурядних речень, зокрема єднальних, може ускладнюватись іншими типами змістових відношень (Білодід, 1972; Вихованець, 1993; Загнітко, 2001; Каранська, 1995; Шитик, 2014). Причину появи додаткових смислів у межах складного речення пояснено в теорії асиметрії мовного знака (поняття введене в науковий обіг С. Карцевським, 1929 р.), сутність якої полягає в тому, що в межах конструкцій, репрезентованих структурною схемою одного типу, може формуватися значення іншого. Першою явище асиметрії в системі складного речення в русистиці цілісно дослідила Т. А. Колосова, зокрема обгрунтувавши у своїй роботі доцільність використання в синтаксичних описах поняття “кількісна асиметрія” (невідповідність кількості предикативних частин, наявних у реченні, кількості пропозицій, заданих його схемною семантикою) (Колосова, 1980). У вітчизняній лінгвістиці на потребі дослідження асиметричних проявів у складних конструкціях як самостійному об’єкті лінгвістичної уваги наголосила С. В. Ломакович. Аналізуючи займенниково-співвідносні речення української мови, синтаксистка грунтовно схарактеризувала асиметричні прояви в цьому класі складних одиниць, увівши в науковий обіг поняття “якісна асиметрія” (невідповідність значення, заданого схемною семантикою, пропозитивній семантиці, що виражена предикативними частинами) (Ломакович, 1993). Окреслена проблема вже була у фокусі нашої уваги, зокрема проаналізовано вияви асиметрії в складнопідрядних реченнях мети в сучасній українській мові (Полозова, 2016). 
Теоретизування уявлень про кількісну і якісну асиметрію сприяло тому, що в більш пізніх дослідженнях складного речення все частіше науковці звертали увагу на ті чи ті прояви синтаксичної асиметрії, зокрема й на рівні складносурядних єднальних речень, які, як засвідчує накопичений мовознавцями матеріал, можуть ускладнюватися додатковими семантичними відтінками як сурядності, так і підрядності.

На сьогодні у вітчизняному мовознавстві проблема складносурядних єднальних речень з ускладненою семантикою знайшла теоретичне осмислення в працях І. Р. Вихованця, М. М. Греб, А. П. Грищенка, М. У. Каранської, І. І. Слинька, Р. О. Хрістіанінової, Л. В. Шитик. Однак у синтаксичній науці до цього часу висловлюють чимало суперечливих поглядів про сутність базових граматичних категорій для складносурядних єднальних речень: про базову семантику цих сурядних конструкцій, про обсяг базового набору формальних ознак, що відповідають цим конструкціям, не встановлено в повному обсязі чинники, які спричиняють виникнення асиметрії в них.

Актуальність дослідження зумовлена потребою узагальнення відомостей про якісно асиметричні прояви на рівні складносурядних єднальних речень в українській мові на основі сучасних уявлень про невідповідність форми й змісту в структурі складних синтаксичних конструкцій. Метою роботи є виявлення кола асиметричних складносурядних єднальних конструкцій зі з'ясуванням інтра- та екстралінгвальних чинників формування в них якісної формально-змістової асиметрії. Основними завданнями дослідження $є$ узагальнення попередніх висновків синтаксистів стосовно додаткових смислів у структурі складносурядних єднальних конструкцій; окреслення основних якісно асиметричних різновидів єднальних речень з увагою до мовних механізмів формування нетипового змісту в них та поясненням прагматичної природи їх появи.

\section{Методи дослідження}

У роботі застосовуємо низку методів дослідження, з-поміж яких описовий - для вивчення й інвентаризації випадків якісної формально-змістової асиметрії в системі складносурядних єднальних речень, трансбормаційного аналізу - для простеження наявності додаткових семантичних нашарувань у межах складносурядних єднальних речень, метод вибірки залучено для відбору фактичного матеріалу. 


\section{Виклад основного матеріалу}

Для з'ясування проявів якісної асиметрії на рівні складносурядних єднальних речень методологічно важливим є окреслення формально-граматичного й семантико-синтаксичного устрою ядерних одиниць, тобто конструкцій, де форма й зміст перебувають у симетричних відношеннях.

На сьогодні формально-граматичний устрій складносурядних речень прийнято аналізувати з огляду на структурну схему, що, за В. А. Бєлошапковою, характеризує загальний синтаксичний механізм формування того чи того виду конструкцій, з погляду кількості поєднуваних предикативних частин і їхніх властивостей; виду синтаксичного зв’язку й засобів його вираження; можливого порядку розташування компонентів стосовно один одного (Шведова, 1970). Відповідно до цього, типовою реалізацією єднальних відношень є складносурядні єднальні речення. На сьогодні виділяють два їх типи - відкритої та закритої структури (Бєлошапкова, 1989: 744).

Складносурядним реченням відкритої структури зі сполучником $i$ та його еквівалентам притаманні відношення одночасності. Сполучник $i$ як асемантичний лише поєднує сурядні частини, тобто стосується загальної ідеї сукупності (співіснування, поєднання), напр.: I сходило соние, $\boldsymbol{i}$ місяиь вставав, $\boldsymbol{i}$ гуси кричали на фоні заграв (Л. Костенко). Семантико-синтаксичні відношення, характерні для складносурядних речень закритої структури, виражає не сполучник $i$, а лексичний склад сурядних частин і структурні особливості складного речення (Вихованець, 1993: 309), а також частково спеціалізовані засоби сполучного характеру (Бєлошапкова, 1989: 745).

Залежно від лексичного наповнення складносурядні речення закритої структури зі сполучником $i$ можуть ускладнюватися різними семантико-синтаксичними відношеннями. Узагальнення інформації, наявної в синтаксичних джерелах, засвідчує, що дослідники визначають різну кількість семантичних модифікацій у межах єднального типу речень, при цьому часто користуючись відмінною термінологією для означення тих самих або подібних семантичних відтінків. Зрозуміло, що це ускладнює цілісне бачення діапазону семантики, здатної розвиватися на базі структурної схеми єднальних конструкцій. 
Зокрема, характеризуючи цей розряд речень, А. П. Грищенко згадує лише причиново-наслідкові, умовно-наслідкові й часові відношення як такі, що можуть розвиватися в їхній структурі внаслідок специфічного наповнення предикативних частин (Білодід, 1972: 395-399). Водночас інші дослідники вказують на те, що в межах цих конструкцій можуть формуватися й інші семантичні відношення, наприклад, зіставні, протиставні, допустові, обмежувальні, градаційні, приєднувальні тощо (Вихованець, 1993: 309; Загнітко, 2001: 345-347, 350-353; Каранська, 1995: 175-179; Шитик, 2014: 230). Зокрема, М. У. Каранська виділяє в межах єднальних речень із неповторюваним сполучником $i$ п'ять різновидів, що розвивають невласне єднальну семантику: зіставлення, наслідковості, висновковості, приєднання й протиставності (Каранська, 1995: 175-178). Додатково дослідниця виділяє в межах єднальних речень зі сполучниками $\breve{u}(i), m a$, ma $\breve{u}$ два типи зі значенням результативності та приєднання (Каранська, 1995: 178-179).

Отже, на сьогодні науковці сходяться в думці, що в структурі єднального типу складносурядних речень формується кілька додаткових семантичних відтінків, що нашаровуються на основну - власне єднальну - семантику. Ці семантично модифіковані реченнєві конструкції $є$ всі підстави кваліфікувати як асиметричні прояви, оскільки в цьому разі спостерігаємо невідповідність формальної структури семантичній. 3 огляду на це слушністю відзначається позиція А. П. Загнітка, який, підтримуючи дослідницьку логіку I.Р. Вихованця, орієнтовану на самостійний опис семантичної організації єднальних конструкцій, зазначає, що «такий підхід найповніше відображає особливості складносурядних речень і водночас вияскравлює корелятивність / некорелятивність формально-синтаксичних відношень у структурі складносурядних речень (Загнітко, 2001: 353).

Виокремлюючи згадані вище різновиди єднальних речень, синтаксисти наголошують, що поява тих чи тих значеннєвих відтінків $€$ наслідком дії чинників різної природи, зокрема: 1) характеру співвідношення предикатів частин; 2) своєрідності засобів зв’язку; 3) наявності анафоричних елементів; 4) наявності специфічної лексичної співвіднесеності частин; 5) комунікативних (інтонаційних) особливостей. Основна група семантично модифікованих єднальних речень (умовно-наслідкові, причиново-наслідкові, протиставні, зіставні, 
результативності, висновковості) формується передусім завдяки специфічному співвідношенню видо-часових форм предикатів, а також специфіці лексичного наповнення предикативних частин (Загнітко, 2001: 346). Водночас важливим чинником формування причиново-наслідкових та умовно-наслідкових конструкцій є модифікація засобів зв'язку. На цьому наголошують, зокрема, М. У. Каранська та А. П. Загнітко (Каранська, 1995; Загнітко, 2001).

Досліджений матеріал дає підстави стверджувати, що на базі єднальних складносурядних речень формуються такі додаткові відтінки семантики: 1) зіставна; 2) протиставна; 3) приєднувальна; 4) умовнонаслідкова; 5) причиново-наслідкова; 6) допустова.

Зіставні відношення в межах складносурядних єднальних речень виникають завдяки специфічному лексико-семантичному наповненню частин, напр.: [Нереальне, все нереальне, пливе-напливає ій перед очі,] сивою каламуттю та грипозною жовтизною заволікається світ, i сама вона вже ніби занурюється в якісь важкі, невилазні води тропіків (О. Гончар); Чоловік мовчав, i всі мовчали (П. Загребельний); Вона щзось шепотіла йому, i він теж відшепочував ій (П. Загребельний). Як відомо, специфіку зіставних речень визначає наявність у частинах лексики однієї тематичної групи. Відповідно в разі подібного наповнення частин, поєднаних єднальними сполучниками, у цілісній конструкції виникає зіставний відтінок, пор.: Ти пращюєщ, $\boldsymbol{i}$ дружина так само не сидить склавши руки (з усн. мовл.), пор.: Ти працюєи, а дружина так само не сидить склавши руки (ти / дружина, працює / не сидить склавши руки). Наведений приклад засвідчує, що загальне значення наведених речень подібне, хоча у власне зіставному семантика зіставності реалізується більш виразно. Очевидно, вибір мовцем того чи того способу оформлення своєї думки залежить від комунікативного наміру й прагматичної мети. У разі використання конструкції з єднальним сполучником удається сформувати дещо м'якшу контрастивність, що, наприклад, може сприяти згладжуванню напруги в комунікативних ситуаціях осуду, нарікання, де зіставні конструкції особливо активні.

У семантичній структурі складносурядних речень як додаткове може виступати відношення протиставності. У таких конструкціях поєднуються компоненти, логічні зв'язки між якими більше протиставні, ніж єднальні. Такі речення мають закритий характер, 
а сполучник $i$ піддається заміні на сполучник але (Каранська, 1995: 177; Слинько, Гуйванюк, \& Кобилянська, 1994: 609; Шитик, 2014: 230), напр.: Щось приходжу я в невідповідність, і чомусь, злочинниия, не каюсь (Л. Костенко), пор.: Щось приходжу я в невідповідність, але чомусь, злочинниия, не каюсь (Вихованець, 1993: 309); Вона хотіла крикнути на нього - i не могла. Хотіла закрити груди руками - й не мала сили їх зняти. Намагалась втекти - i вросла в землю (М. Коцюбинський), пор.: Вона хотіла крикнути на нього, але не могла. Хотіла закрити груди руками, але не мала сили ї зняти. Намагалась втекти, але вросла в землю. Семантика протиставлення виникає в реченнях унаслідок появи невідповідності через уживання в предикативних частинах контекстуально антонімічних присудків (хотіла крикнути - не могла; хотіла закрити - не мала сили зняти; намагалась втекти - вросла).

Отже, досліджений матеріал засвідчує, що чинником формування зіставної і протиставної семантики на базі єднальних складнопідрядних речень $є$ специфічне лексико-семантичне наповнення предикативних частин.

Для єднальних речень може бути характерним приєднувальний відтінок значення. У таких конструкціях другий фрагмент щось зауважує стосовно сказаного в першому, щось підкреслює, виділяє. Така друга предикативна частина разом зі сполучником $i$ додається після спеціальної приєднувальної паузи видозміненою інтонацією з особливим наголошенням. Часто друга частина $є$ неповною, їй властива емоційність, тому перед сполучником $i$ нерідко ставиться тире, напр.: Час у них $\epsilon$, $\boldsymbol{i}$ багато часу. У наших стосунках прогрес відсутній - $\boldsymbol{i}$ не 3 моєї вини (Каранська, 1995: 176-177; Слинько, Гуйванюк, \& Кобилянська, 1994: 609; Шитик, 2014: 230). Отже, у цьому разі важливу роль відіграє комунікативна організація речення, тобто чинником формування формально-змістової асиметрії $є$ специфіка тема-рематичного членування.

Завдяки лексичному наповненню в складносурядних реченнях $з$ асемантичним сполучником $i$ можуть виникати причиновонаслідкові та умовно-наслідкові відношення, що характеризуються своєрідним співвідношенням формального й семантичного аспектів: між синтаксично рівноправними предикативними частинами наявні семантико-синтаксичні відношення, властиві складнопідрядному 
реченню (Вихованець, 1993: 313; Загнітко, 2001: 346; Слинько, Гуйванюк, \& Кобилянська, 1994: 608; Шитик, 2014: 264-265).

Складники таких речень неоднотипні, тому, на відміну від власне єднальних речень, характеризуються незворотністю частин і закритістю структури, напр.: Задощило, $\boldsymbol{i}$ фільмування довелося припинити (О. Гончар), пор.: Задощило, так що фільмування довелося припинити; Фільмування довелося припинити, бо задощило; А потім настала весна, зігнало геть хмари, i відкрилося небо таке високе, таке блакитне, зовсім як небо Італіки! (О. Гончар), пор.: А потім настала весна, зігнало геть хмари, так що відкрилося небо таке високе, таке блакитне, зовсім як небо Італіки!; [Над нами водно посвистують кулі,] виілить якась - і місяцьь шпиталю (Р. Іваничук), пор.: Якщо вцілить якась, то місяиь шпиталю; Син скромний - i батько щасливий (Нар. тв.), пор.: Якщо син скромний, то батько щзасливий. Крім згаданих, єднальні відношення можуть ускладнюватися відтінком висновковості, що фактично є своєрідною периферією причино-наслідкових. Єднальний зв'язок у таких реченнях грунтується на відношеннях підстави й висновку між їх компонентами (Каранська, 1995: 176; Слинько, Гуйванюк, \& Кобилянська, 1994: 608), напр.: Група отримала гарні оцінки за роботу, $\boldsymbol{i}$ ие заслуговує схвалення; Я тобі не дружина, $\boldsymbol{i}$ не треба тут командувати.

А. П. Грищенко поміж іншим звертає увагу на той факт, що поширеними щодо вираження умовної семантики в межах єднальних $€$ конструкції, де в першій частині міститься дієслово у формі наказового способу, а в другій - дієслівні форми переважно майбутнього часу, однак не пропонує цьому факту пояснення (Білодід, 1972: 398). Видається, що продуктивність цих асиметричних єднальних конструкцій зумовлена тим, що в реальних ситуаціях живої комунікації чимало контекстів (на зразок поради, підтримки, обміну досвідом, наказу й под.), у яких є необхідність виразити умовну семантику, актуалізуватимуть не значення жорсткої каузації, а значення закономірного розвитку наступної події в разі реалізації попередньої. Зокрема, у живому мовленні фіксуємо конструкції на зразок [Якщо вас зацікавила наша пропозиція,] будь ласка, напишіть - $\boldsymbol{i}$ ми зв'яжемося з вами. (www.kyivstar.ua); [Дорога п. Михайлино! Прийила коректа все о-кей. Чи міг би я післати Вам «Щоденник» А[ркадія] Л[юбченка] (якщо у Вас немає)?] напишіть, і я радо вишлю Вам ие в "нагороду" 
за передмову. Ваш Ю. Л. (М. Коцюбинська); Зробіть домашнє завдання, $\boldsymbol{i}$ я поставлю вам оцінку (з усн. мовл.), що сприймаються як менш жорсткі, більш позитивно орієнтовані, ніж їхні аналоги складнопідрядної природи. Те, що умовні конструкції відзначаються більшою категоричністю, пояснюємо зумовленістю двох ситуацій (якщо зробите, то поставимо; якщо напишете, то зв'яжемося), єднальні ж конструкції мають іншу іллокутивну силу через те, що дві події не $є$ залежними одна від одної, мовець запевняє в обов'язковому настанні результату, тобто від реципієнта майже нічого не залежить (“лише” напишіть, “лише” зробіть домашнє завдання).

Отже, чинниками формування причиново-наслідкової й умовно-наслідкової семантики в єднальних складносурядних реченнях $€$ часово-способова специфіка предикатів, лексичне наповнення частин та контекст. Такі речення не відповідають формальному зразку, що зумовлює суттєву трансформацію їхнього змісту, а саме його ускладнення, він може бути виражений у структурі складнопідрядних детермінантних речень, тому такі складносурядні речення, безперечно, можна вважати асиметричними.

Єднальні речення можуть ускладнюватися додатковим відтінком допустовості (Слинько, Гуйванюк, \& Кобилянська, 1994: 606), напр.: Бився з ворогами у самому пеклі, і кулі минали його (І. Цюпа), пор.: Хоча бився з ворогами у самому пеклі, але кулі минали його. Допустове значення корелює з протиставним. У реченнях, що виражають допустові відношення, зіставляються дві ситуації. Одна з них репрезентована в першій частині та є базовою для ситуації, яка протилежна за будь-якою ознакою тій, про яку йдеться в іншій частині. Зворотний характер зумовленості в допустових реченнях, окрім вираження за допомогою сполучників, репрезентовано також лексично - у значенні предикатів та їхньому оточенні. Через те, що сполучник, який маркує наявність у реченні допустової семантики, не вживається в єднальних реченнях, особливо важливим стає лексико-семантичне наповнення предикативних частин: це частки усе-таки, усе одно, усе ж, використання яких характерне й для детермінантних допустових речень, а також контрастні предикатні лексеми першої й другої предикативних частин, а саме лексеми, узуально або контекстуально антонімічні за значенням, як, наприклад, у реченнях: Плодів на пальмах уже не було - одноплеміниі давно пообтрушували, і все-таки 
виснажені насамони пролежали під пальмами иілих три доби, відпиваючись джерельною водою (Іван Білик), пор.: Хоча плодів на пальмах уже не було - одноплемінці давно пообтрушували, але виснажені насамони пролежали під пальмами цілих три доби, відпиваючись джерельною водою; Вже несила сміятися - задихався, гортаючи закляклими пальиями папери на столі, і все одно вичавлював з грудей штучні клекоти (В. Дрозд), пор.: Хоча вже несила сміятися - задихався, гортаючи закляклими пальиями папери на столі, але вичавлював з грудей шттучні клекоти; Звичайно ж, причина изєї заяви була иілком зрозуміла, і все ж йому стало дещо неприємно (М. Дашкієв), пор.: Хоча, звичайно ж, причина иієї заяви була иілком зрозуміла, але йому стало дещь неприємно. Отже, формування допустової семантики на базі складносурядних єднальних речень спричиняє лексичне наповнення предикативних частин, зокрема контрастними предикатними лексемами, а також ускладнення засобу зв'язку.

\section{Висновки}

Отже, досліджений фактичний матеріал засвідчує, що єднальні складносурядні речення мають високий ступінь розгалуженості семантики, яка може розвиватися на основі сурядного синтаксичного зв’язку. Цей факт можна витлумачити відносною “спустошеністю” єднального сполучника $i$, що задає лише в загальному відношення між частинами, хоча й накладає певні обмеження, а також когнітивною природою операції кон'юнкції як простого співположення у свідомості мовця двох ситуацій дійсності, між якими може поступово окреслюватися суб’єктивно інтерпретований широкий діапазон залежності.

Крім того, серед причин актуалізації формально-змістової асиметрії варто розглядати прагматичні фактори: сурядність виявляється благодатним грунтом для вираження, так би мовити, недооформлених залежностей між пропозиціями. Це стає в пригоді мовцю під час реалізації арсеналу комунікативних інтенцій та підтримки різноманітних тактик і стратегій.

Перспективою досліджень є подальше вивчення складносурядних речень, виявлення кола асиметричних складносурядних конструкцій в українській мові, а також інтра- та екстралінгвальних факторів, що зумовлюють виникнення невідповідності синтаксичної форми ії ядерному змісту. 


\section{ЛІТЕРАТУРА}

1. Белошапкова, В. А. (Ред.). (1989). Современный русский язык. Синтаксис. Москва: Высш. шк. 2. Білодід, І. К. (Ред.). (1972). Сучасна украйнська літературна мова: Синтаксис. Київ: Наук. думка. 3. Вихованець, І. Р. (1993). Граматика украӥнської мови. Синтаксис. Київ: Либідь. 4. Загнітко, А. П. (2001). Теоретична граматика украйнської мови: Синтаксис. Донецьк: ДонНУ. 5. Каранська, М. У. (1995). Синтаксис сучасної украӥнської літературної мови. Київ: Либідь. 6. Колосова, Т. А. (1980). Русские сложные предложения асимметричной структуры. Воронеж: Изд-во Воронеж. ун-та. 7. Ломакович, С. В. (1993). Займенниково-співвідносні речення в сучасній українській мові. (Дис. ... докт. філол. наук). Тернопіль: Терноп. держ. пед ін-т. 8. Полозова, О. О. (2016). Асиметричні прояви на рівні складнопідрядних речень мети в сучасній українській мови. Лінгвістичні дослідження, 44, 68-76. http://doi. org/10.5281/zenodo.165070. 9. Слинько, I. I., Гуйванюк, Н. В., \& Кобилянська, М. Ф. (1994). Синтаксис сучасної украӥнської мови: Проблемні питання. Київ: Вища шк. 10. Шведова, Н. Д. (Ред.). (1970). Русская грамматика. Москва: Наука. 11. Шитик, Л. (2014). Синхронна перехідність синтаксичних одиниць в украйнській літературній мові. Черкаси: Вид. Чабаненко Ю. А.

\section{REFERENCES}

1. Beloshapkova, V. A. (Ed.). (1989). Sovremennyiy russkiy yazyik. Sintaksis [Modern Russian language. Syntax]. Moskva: Vyissh. shk. [in Russian]. 2. Bilodid, I. K. (Red.). (1972). Suchasna ukrainska literaturna mova: Syntaksys [Modern Ukrainian literary language: Syntax]. Kyiv: Nauk. dumka [in Ukrainian]. 3. Vykhovanets, I. R. (1993). Hramatyka ukrainskoi movy. Syntaksys [Grammar of the Ukrainian language. Syntax]. Kyiv: Lybid [in Ukrainian]. 4. Zahnitko, A. P. (2001). Teoretychna hramatyka ukrainskoi movy: Syntaksys [Theoretical grammar of the Ukrainian language: Syntax]. Donetsk: DonNU [in Ukrainian]. 5. Karanska, M. U. (1995). Syntaksys suchasnoi ukrainskoi literaturnoi movy [Syntax of modern Ukrainian literary language]. Kyiv: Lybid [in Ukrainian]. 6. Kolosova, T. A. (1980). Russkie slozhnyie predlozheniya asimmetrichnoy strukturyi [Russian complex sentences of asymmetric structure]. Voronezh: Izd-vo Voronezh. un-ta [in Russian]. 7. Lomakovych, S. V. (1993). Zaimennykovo-spivvidnosni rechennia $\mathrm{v}$ suchasnii ukrainskii movi [Pronoun-relative sentences in the modern Ukrainian language]. Doctor's thesis. Ternopil: Ternop. derzh. ped inst. [in Ukrainian]. 8. Polozova, O. O. (2016). Asymetrychni proiavy na rivni skladnopidriadnykh rechen mety $\mathrm{v}$ suchasnii ukrainskii movy [Asymmetric manifestations at the level of complex sentences of purpose in the modern Ukrainian language]. Linhvistychni doslidzhennia - Linguistic research, 44, 68-76. http://doi.org/10.5281/zenodo.165070. 9. Slynko, I. I., Huivaniuk, N. V., \& Kobylianska, M. F. (1994). Syntaksys suchasnoi ukrainskoi movy: Problemni pytannia [Syntax of the modern Ukrainian language: Problematic issues]. Kyiv: Vyshcha shk. [in Ukrainian]. 10. Shvedova, N. D. (Red.). (1970). Russkaya grammatika [Russian grammar]. Moskva: Nauka [in Russian]. 11. Shytyk, L. (2014). Synkhronna perekhidnist syntaksychnykh odynyts $v$ ukrainskii literaturnii movi [Synchronous transition of syntactic units in the Ukrainian literary language]. Cherkasy: Vyd. Chabanenko Yu. A. [in Ukrainian]. 
Полозова Олена Олександрівна - кандидат філологічних наук, доцент кафедри українознавства і лінгводидактики, Харківський національний педагогічний університет імені Г. С. Сковороди; вул. Валентинівська, 2, м. Харків, 61168, Україна.

Tel.: +38-097-819-06-57

E-mail: polozoval@ukr.net

http://orcid.org/0000-0002-6780-1764

Polozova Olena Oleksandrivna - Candidate of Philological Sciences (Ph.D.), Associate Professor at the Department of Ukrainian Studies and Linguistic Didactics, H. S. Skovoroda Kharkiv National Pedagogical University; 2 Valentynivska Str., Kharkiv, 61168, Ukraine.

Надійшла до редакції 22 березня 2021 року

\section{CITATION}

ДСТУ 8302:2015: Полозова О. О. Мовні чинники й механізми формування якісної формально-змістової асиметрії в єднальних складносурядних реченнях. Лінгвістичні дослідження: зб. наук. пр. Харк. нац. пед. ун-ту імені Г. С. Сковороди. Харків, 2021. Вип. 54. Ч. II. С. 57-68. DOI: https://doi.org/10.34142/23127546.2021.54.2.06

APA: Полозова, О. О. (2021). Мовні чинники й механізми формування якісної формально-змістової асиметрії в єднальних складносурядних реченнях. Лінгвістичні дослідження, 54 (II), 57-68. DOI: https://doi.org/10.34142/23127546.2021.54.2.06 